\title{
Front Matter: Volume 10195
}

, "Front Matter: Volume 10195," Proc. SPIE 10195, Unmanned Systems Technology XIX, 1019501 (26 June 2017); doi: 10.1117/12.2281256

SPIE. Event: SPIE Defense + Security, 2017, Anaheim, CA, United States 


\title{
PROCEEDINGS OF SPIE
}

\section{Unmanned Systems Technology XIX}

\author{
Robert E. Karlsen \\ Douglas W. Gage \\ Charles M. Shoemaker \\ Hoa G. Nguyen \\ Editors
}

11-13 April 2017

Anaheim, California, United States

Sponsored and Published by

SPIE 
The papers in this volume were part of the technical conference cited on the cover and title page. Papers were selected and subject to review by the editors and conference program committee. Some conference presentations may not be available for publication. Additional papers and presentation recordings may be available online in the SPIE Digital Library at SPIEDigitallibrary.org.

The papers reflect the work and thoughts of the authors and are published herein as submitted. The publisher is not responsible for the validity of the information or for any outcomes resulting from reliance thereon.

Please use the following format to cite material from these proceedings:

Author(s), "Title of Paper," in Unmanned Systems Technology XIX, edited by Robert E. Karlsen, Douglas W. Gage, Charles M. Shoemaker, Hoa G. Nguyen, Proceedings of SPIE Vol. 10195 (SPIE, Bellingham, WA, 2017) Seven-digit Article CID Number.

ISSN: 0277-786X

ISSN: 1996-756X (electronic)

ISBN: 9781510608917

ISBN: 9781510608924 (electronic)

Published by

SPIE

P.O. Box 10, Bellingham, Washington 98227-0010 USA

Telephone +1 3606763290 (Pacific Time) · Fax +1 3606471445

SPIE.org

Copyright (c) 2017, Society of Photo-Optical Instrumentation Engineers.

Copying of material in this book for internal or personal use, or for the internal or personal use of specific clients, beyond the fair use provisions granted by the U.S. Copyright Law is authorized by SPIE subject to payment of copying fees. The Transactional Reporting Service base fee for this volume is $\$ 18.00$ per article (or portion thereof), which should be paid directly to the Copyright Clearance Center (CCC), 222 Rosewood Drive, Danvers, MA 01923. Payment may also be made electronically through CCC Online at copyright.com. Other copying for republication, resale, advertising or promotion, or any form of systematic or multiple reproduction of any material in this book is prohibited except with permission in writing from the publisher. The CCC fee code is 0277-786X/17/\$18.00.

Printed in the United States of America.

Publication of record for individual papers is online in the SPIE Digital Library.

\section{SPIE. DIGITAL \\ SPIEDigitalLibrary.org}

Paper Numbering: Proceedings of SPIE follow an e-First publication model. A unique citation identifier (CID) number is assigned to each article at the time of publication. Utilization of CIDs allows articles to be fully citable as soon as they are published online, and connects the same identifier to all online and print versions of the publication. SPIE uses a seven-digit CID article numbering system structured as follows:

- The first five digits correspond to the SPIE volume number.

- The last two digits indicate publication order within the volume using a Base 36 numbering system employing both numerals and letters. These two-number sets start with 00, 01, 02, 03, 04, 05, 06, 07, 08, 09, OA, OB ... OZ, followed by 10-1Z, 20-2Z, etc. The CID Number appears on each page of the manuscript. 


\title{
Contents
}

\author{
vii Authors \\ ix Conference Committee \\ xiii Introduction
}

ROBOTICS CTA

1019502 Assessment of RCTA research [10195-1]

1019503 Using deep learning to bridge the gap between perception and intelligence [10195-2]

1019504 Gait design and optimization for efficient running of a direct-drive quadrupedal robot [10195-3]

1019505 Ground-based self-righting using inertial appendage methods [10195-4]

\section{MOBILITY AND NAVIGATION}

1019506 Experimental verification of distance and energy optimal motion planning on a skidsteered platform [10195-5]

1019507 Kinematic modeling of a RHex-type robot using a neural network [10195-6]

1019508 Autonomous UAV search planning with possibilistic inputs [10195-7]

1019509 Online location recognition for drift-free trajectory estimation and efficient autonomous navigation [10195-8]

\section{PERCEPTION}

10195 OB Rapid abstract perception to enable tactical unmanned system operations [10195-10]

10195 OC Biologically-inspired approach to automatic processing of fly eye radar antenna array patterns with convolutional neural networks [10195-11]

\section{ONR 30 GROUND VEHICLE AUTONOMY I}

10195 OE ONR 30 autonomous ground system program overview [10195-13]

10195 OF A perception pipeline for expeditionary autonomous ground vehicles [10195-14]

$101950 \mathrm{O}$ Adaptive terrain traversability estimation using passive sensing [10195-16] 
$10195 \mathrm{OH}$ Wheel placement reasoning in complex terrain [10195-17]

$10195 \mathrm{Ol} \quad$ Augmenting autonomous vehicle sensor processing with prior data [10195-18]

\section{ONR 30 GROUND VEHICLE AUTONOMY II}

$101950 \mathrm{~J}$ Mission modeling, planning, and execution module for teams of unmanned vehicles [10195-19]

10195 OK Adaptive formation control for route-following ground vehicles [10195-20]

10195 OL Designing an operator control unit for cooperative autonomous unmanned systems [10195-21]

10195 OM A systematic approach to autonomous unmanned system experimentation [10195-22]

10195 ON Best practices for autonomous vehicle configuration management [10195-23]

SELF-ORGANIZING, COLLABORATIVE UNMANNED ROBOTIC TEAM: JOINT SESSION WITH CONFERENCES 10195 AND 10205

1019500 CARACaS multi-agent maritime autonomy for unmanned surface vehicles in the Swarm II harbor patrol demonstration [10195-24]

\section{COMMUNICATION SYSTEMS FOR SMALL UNMANNED VEHICLES}

10195 OP Joint Communications Architecture for Unmanned Systems (JCAUS) (Invited Paper) [10195-26]

$101950 Q \quad$ Development of an advanced cybersecure radio for small unmanned ground vehicles [10195-27]

10195 OR Cybersecurity for unmanned systems [10195-28]

HRI

10195 OT Multi-modal interaction for robotics mules [10195-30]

$10195 \mathrm{OU}$ Head-worn display for control of unmanned vehicles [10195-31]

10195 OV Safeguarding autonomy through intelligent shared control [10195-32]

10195 OW Unobtrusive and assistive obstacle avoidance for tele-operation of ground vehicles [10195-33]

iv 
$101950 X \quad$ Assessing autonomy vulnerabilities in military vehicles [10195-34]

10195 OY The 25th Annual Intelligent Ground Vehicle Competition (IGVC): building engineering students into roboticists [10195-35]

$101950 Z$ A class of polarized cavity orientation sensors [10195-36]

1019510 Deep-learning trust estimation in multi-agent systems [10195-37]

1019511 Fast reinforcement learning based distributed optimal flocking control and network co-design for uncertain networked multi-UAV system [10195-38]

1019512 Model-free adaptive controller for autonomous aerial transportation of suspended loads with unknown characteristics [10195-39]

\section{POSTER SESSION}

1019513 Wireless energy and data transfer to munitions using high power laser diodes [10195-40]

1019514 Development of an app-on-demand capability for unmanned systems [10195-41]

1019515 A testing and demonstration mission for an automated spacecraft repair system [10195-42]

$1019516 \quad$ UAV path planning in absence of GPS signals [10195-43]

1019517 Size and rotation invariant alphabet recognition [10195-44]

1019518 UAVs: on development of fuzzy model for categorization of countermeasures during threat assessment [10195-45] 
Proc. of SPIE Vol. $101951019501-6$

Downloaded From: https://www.spiedigitallibrary.org/conference-proceedings-of-spie on 26 Apr 2023 Terms of Use: https://www.spiedigitallibrary.org/terms-of-use 


\section{Authors}

Numbers in the index correspond to the last two digits of the seven-digit citation identifier (CID) article numbering system used in Proceedings of SPIE. The first five digits reflect the volume number. Base 36 numbering is employed for the last two digits and indicates the order of articles within the volume. Numbers start with 00, 01, 02, 03, 04, 05, 06, 07, 08, 09, 0A, 0B...0Z, followed by 10-1Z, 20-2Z, etc.

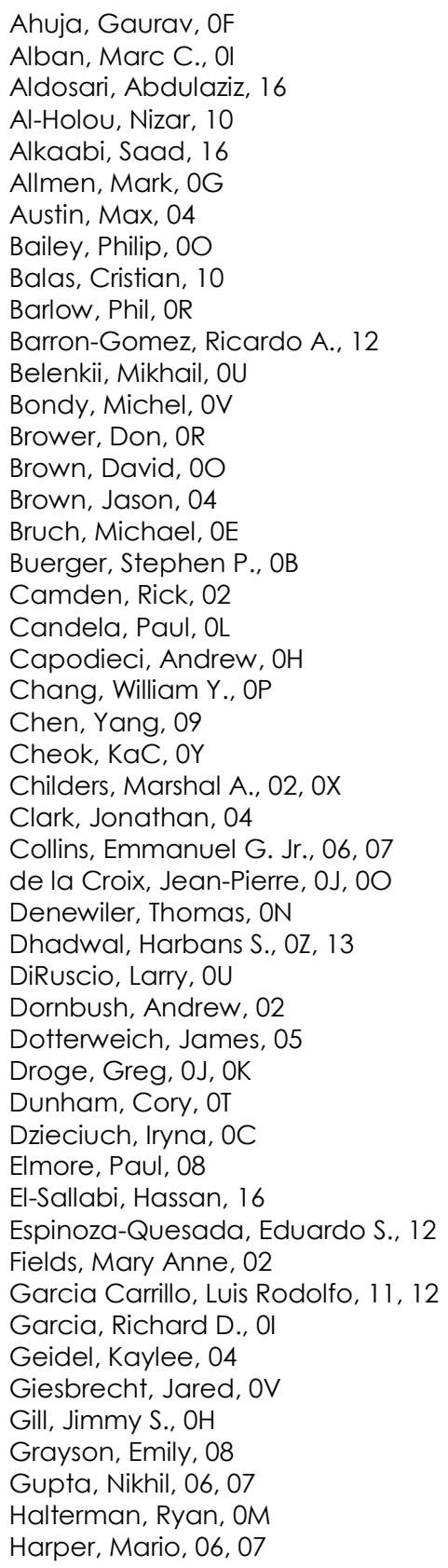

Hart, Abraham, $0 Q$

Hassman, Mark, OG

Hebert, Martial, 03

Jasiobedzki, Piotr, OV, OW

Johnson, Elliot R., Ol

Kamthan, Shashank, 18

Karlsen, Robert, 10

Kelley, Leah, OE

Kessens, Chad C., 05

Khosla, Deepak, 09

Kim, Kyungnam, 09

Koch, Mark W., OB

Kosinski, Andrew, OY

Kozak, Kristopher C., Ol

Kwok, Philip, 0Z, 13

Lane, Gerald, oy

Lanting, Matthew, OT

Lebiere, Christian, 02

Lee, Chulhee, 17

Lee, Daren, OF

Lennon, Craig T., 02, 0X

Lim, Christopher, 00

Lim, Grace, 0J

Marinier, Robert, OT

Martin, Michael, 02

Meitzler, Thomas, 18

Mikulski, Dariusz, 10

Muench, Paul, OT, 10

Nans, Adam, OL

Nash, Jeremy, OF

$\mathrm{Ng}$, Ho-Kong, OV

Nguyen, Hoa G., OQ

Nguyen, Viet, $0 \mathrm{O}$

Ollis, Mark D., $\mathrm{OH}$

Ordonez, Camilo, 06, 07

Pace, James, 06, 07

Papon, Jeremie, OF

Parikh, Anup, OB

Pereira, C., $\mathrm{OZ}$

Petry, Fred, 08

Pezeshkian, Narek, $0 Q$

Pomerantz, Marc, 00

Quist, Michael, OT

Rahmani, Amir, OJ, OK, 00

Ramos-Velasco, Luis E., 12

Rankin, Arturo, $\mathrm{OF}$

Rastegar, Jahangir, 0Z, 13

Reese, Shad M., OP

Ricks, Jason, OR 
Rim, Junho, 17

Rudisel, Brandon, 14

Sandoval, Michael, 00

Sapronov, Lenny, 02

Schaffer, Steve, 00

Scrapper, Chris J., OE, OJ, OK, OM

Sharma, Aneesh, 06

Singh, Daljit, OR

Singh, Harpreet, 18

Smigal, John, OR

Sofge, Don, 08

Sorice, Cristina, 00

Spencer, Steven J., OB

Straub, Jeremy, 14, 15

Suppé, Arne J., 03

Sverdrup, Lawrence, OU

Taketomi, Yoshi, OU

Tang, John, OV

Tarakhovsky, Jane, OY

Taylor, Glenn, 0T

Tepsuporn, Scott, 00

Theisen, Bernie, OY

Tjersland, Mark, ON

Vander Hook, Joshua, 0J, 00

Wang, Wenxuan, 04

Weller, Ed, 02

Wiitamaki, Alex D., 15

Wolf, Michael T., 00

Woodward, Gail, 00

$\mathrm{Xu}, \mathrm{HaO}, 11,12$

$\mathrm{XU}$, Jiejun, 09

Xydes, Alexander, OJ, OK, OL

Yen, John, OQ, OR

Zapf, Josh, OF

Zhang, Mingfeng, OV, OW 


\section{Conference Committee}

Symposium Chair

Donald A. Reago Jr., U.S. Army Night Vision \& Electronic Sensors

Directorate (United States)

Symposium Co-chair

Arthur A. Morrish, Raytheon Space and Airborne Systems

(United States)

Conference Chairs

Robert E. Karlsen, U.S. Army Tank Automotive Research, Development and Engineering Center (United States)

Douglas W. Gage, XPM Technologies (United States)

Charles M. Shoemaker, U.S. Army Communications-Electronics Research Development and Engineering Command (United States)

Hoa G. Nguyen, Space and Naval Warfare Systems Center Pacific (United States)

Conference Program Committee

Jonathan A. Bornstein, U.S. Army Research Laboratory (United States) Jared Giesbrecht, Defence Research and Development Canada, Suffield (Canada)

Frank L. Lewis, The University of Texas at Arlington (United States)

Larry H. Matthies, Jet Propulsion Laboratory (United States)

Camille S. Monnier, Charles River Analytics, Inc. (United States)

Paul L. Muench, U.S. Army Tank Automotive Research, Development and Engineering Center (United States)

Dilip G. Patel, General Dynamics Robotic Systems (United States)

Gary Witus, Turing Associates, Inc. (United States)

\section{Session Chairs}

1 Robotics CTA

Dilip G. Patel, General Dynamics Robotic Systems (United States)

Jonathan A. Bornstein, U.S. Army Research Laboratory (United States)

2 Mobility and Navigation

Camille S. Monnier, Charles River Analytics, Inc. (United States)

Paul L. Muench, U.S. Army Tank Automotive Research, Development and Engineering Center (United States) 
3 Perception

Camille S. Monnier, Charles River Analytics, Inc. (United States)

Paul L. Muench, U.S. Army Tank Automotive Research, Development and Engineering Center (United States)

4 Advanced Sensor Systems for Human-Machine Teaming I: Joint session with conferences 10194 and 10195

Jamie Lukos, Space and Naval Warfare Systems Command (United States)

William D. Nothwang, U.S. Army Research Laboratory (United States)

5 Advanced Sensor Systems for Human-Machine Teaming II: Joint session with conferences 10194 and 10195

Jamie Lukos, Space and Naval Warfare Systems Command (United States)

William D. Nothwang, U.S. Army Research Laboratory (United States)

6 ONR 30 Ground Vehicle Autonomy I

Michael H. Bruch, SPAWAR Systems Center Pacific (United States)

Ryan Halterman, SPAWAR Systems Center Pacific (United States)

7 ONR 30 Ground Vehicle Autonomy II

Michael Bruch, SPAWAR Systems Center Pacific (United States)

Ryan Halterman, SPAWAR Systems Center Pacific (United States)

8 Self-organizing, Collaborative Unmanned Robotic Team: Joint session with conferences 10195 and 10205

Raja Suresh, General Dynamics Mission Systems (United States)

9 Communication Systems for Small Unmanned Vehicles

Hoa G. Nguyen, Space and Naval Warfare Systems Center Pacific (United States)

Roger Khazan, MIT Lincoln Laboratory (United States)

$10 \mathrm{HRI}$

Robert Karlsen, U.S. Army Tank Automotive Research, Development and Engineering Center (United States)

Charles M. Shoemaker, U.S. Army Communications-Electronics Research Development and Engineering Command (United States) 


\section{Special Topics}

Robert Karlsen, U.S. Army Tank Automotive Research, Development and Engineering Center (United States)

Charles M. Shoemaker, U.S. Army Communications-Electronics Research Development and Engineering Command (United States)

Proc. of SPIE Vol. $101951019501-11$

Downloaded From: https://www.spiedigitallibrary.org/conference-proceedings-of-spie on 26 Apr 2023 Terms of Use: https://www.spiedigitallibrary.org/terms-of-use 
Proc. of SPIE Vol. 10195 1019501-12 Downloaded From: https://www.spiedigitallibrary.org/conference-proceedings-of-spie on 26 Apr 2023
Terms of Use: https://www.spiedigitallibrary.org/terms-of-use 


\section{Introduction}

The Unmanned Systems Technology XIX Conference consisted of eight sessions and three joint sessions that spanned two and a half days and covered a variety of areas within robotics. The conference's list of papers shows a wide breadth of applications for unmanned systems, primarily in the defense arena, with a good mix of papers from the ground, air, sea and space domains. This variety demonstrates why robotics is such an interesting and exciting area within which to work.

This year the conference began Tuesday afternoon with a session from the Army Research Laboratory's (ARL) Robotics Collaborative Technology Alliance (CTA) that included papers on an experiment involving a small robot maneuvering towards and grasping an object of interest, the use of deep learning for understanding of covert behavior, gait strategies for efficient legged locomotion, and the incorporation of dynamics in self-righting. This was followed by a session on Mobility and Navigation, with papers discussing energy efficiency of skid steering robots, a comparison between neural networks of escalating complexity for the modeling of a simple legged robot, the use of fuzzy logic and possibility theory in adding a priori knowledge to UAV search algorithms, previous location recognition for an indoor UAV using computationally efficient image keypoint descriptor and detector, and control mechanism for a CubeSat. A small Perception session had two papers, one on tactical autonomy that included experiments differentiating mannequins, cardboard cutouts and humans and the other a conceptual paper on the potential for a radar system patterned after a fly's eye. Tuesday concluded with the conference's poster session, which included a paper on rapid wireless energy and data transfer via laser diodes, a concept for automated repair of spacecraft, a concept for navigation of a UAV without GPS using cell network signals, efficient text recognition using an angledistance map, and fuzzy logic model for vehicle collisions and countermeasures. The poster session was well attended again this year.

Wednesday morning involved two joint sessions with Conference 10194, Microand Nanotechnology Sensors, Systems, and Applications IX, consisting of work performed under the Office of the Secretary Defense (OSD) Autonomy Research Project Initiative (ARPI) and focused on Human Machine Teaming. The first session began with a keynote address that described a number of projects on human machine teaming. Subsequent papers involved an experiment involving driving with variable-reliability automation, an operator interface that provided uncertainty information to the operator, an autonomy system that interacts with the operator to gain understanding, and models and experiments on human cyber physical systems involving teleoperation. The second session consisted of papers on the conceptual use of multi-UxV planning and task loading with 
machine learning, decentralized planning in a UAV target search scenario, and cognitive understanding of the objects in an environment.

Wednesday afternoon consisted of two sessions concerning research from the Office of Naval Research (ONR) Code 30 in Ground Vehicle Autonomy, which were organized by Space and Naval Warfare Systems Center Pacific (SSC Pacific). The first session led off with an overview of ONR 30 research projects supporting the development of autonomous expeditionary capability, followed by papers on end-to-end perception processing, traversability estimation and world models, wheel placement near obstacles, and fusing vehicle sensor data with data from other sources. The second session had papers on mission planning for a team of unmanned route clearance vehicles, formation control using a virtual spring/damper mechanism, development of an operator control unit built on MOCU 4, a process for conducting unmanned vehicle experimentation, and methods to achieve reliable autonomous systems.

Thursday morning led off with a joint session with Conference 10205, Open Architecture/Open Business Model Net-Centric Systems and Defense Transformation 2017. The session was on Self-organizing, Collaborative Unmanned Robotic Team and two papers were presented, the first on the architecture for a small team of UAS with members possessing different RF capabilities and the second on an experiment involving heterogeneous surface vessels performing a harbor patrol mission. Immediately following was a session on Communication Systems for Small Unmanned Ground Vehicles, which began with a paper on the development of a joint architecture for communications and radios, followed by a paper on developing a small modular secure radio and another describing issues and procedures for implementing cyber security in unmanned systems.

The conference concluded with the afternoon sessions on Thursday, the first of which involved papers on Human Robot Interactions (HRI), including research on multi-modal speech and gesture interactions, a head-worn display and eyecontrol mechanism, shared control with a variety of semi-autonomous assistance functions, and a method for unobtrusive guarded teleoperation. The final session of the conference was the Special Topics session that included a wide range of topics including papers on assessing the vulnerability of autonomous truck convoys, a collegiate robotics competition, an all-weather orientation sensor for munitions, a deep learning trust algorithm for unmanned convoys, a flocking UAV algorithm that is robust to communication packet dropping, and a UAV controller that learns how to adapt to a suspended load. 
The conference for the first time was held in Anaheim, CA, which provided a very nice facility and location. Next year the conference will hit the twenty-year mark and will take place in Orlando, FL, where it began in 1999. We want to thank all those that helped make the conference a success this year and we hope that you enjoy these proceedings and are able to attend and participate in the conference next year.

Robert E. Karlsen Douglas W. Gage Charles M. Shoemaker Hoa G. Nguyen 
Proc. of SPIE Vol. 10195 1019501-16

Downloaded From: https://www.spiedigitallibrary.org/conference-proceedings-of-spie on 26 Apr 2023 Terms of Use: https://www.spiedigitallibrary.org/terms-of-use 